\title{
The Role of the State in the Process of Institutional Evolvement in Agricultural Land after the Founding of PRC
}

\author{
Xin Shang \\ College of Economics and Management, Jilin Agricultural University \\ Changchun 130118, China \\ $\&$ \\ School of Economics \& Management, Changchun University of Science and Technology \\ Changchun 130022, China \\ E-mail: shangxin401@163.com \\ Qinghai Guo \\ College of Economics and Management, Jilin Agricultural University \\ Changchun 130118, China
}

\begin{abstract}
On the basis of elaborating the process of institutional change of Chinese agricultural land and by reference to the State Theory of North, the article analyzes constituent functions for institutional activities by the state for its realization of maximization of utility and further the role of the state in the process of institutional change of Chinese agricultural land.
\end{abstract}

Keywords: State Theory, Maximization of utility, Evolvement of Agricultural land system

\section{Introduction}

Institutional change of agricultural land after the founding of People's Republic of China (PRC) was finished under guide of the state. As a matter of fact, agricultural land went through the three processes: average allocation of agricultural land resources among peasant households (private land ownership from 1947 to 1952), unified state allocation (collective economic system from 1952 to 1978) and average allocation of agricultural land resources among peasant households (the household contract responsibility system from 1978 until now). The role of the state in economic development has aroused wide attention from economists. According to North, economic activities of the state were finished by a dominator with bounded rationality, and the state was an organization with comparative advantage in terms of implementation of violence. He believed, the state had the competence to employ violence with potential to realize control over resources an applied the Pillage Theory and Contract Theory to explain why economy of the state during most periods in the history was in a state of economic recession, (North, 1992). Justin Lin pointed out in his research on institutional change, either the imposed institutional change implemented compulsorily by the state, or the induced institutional change under temptation of profitable opportunities by an individual, could not go without the role of the state, (Justin Lin). Zhou Qiren made a relatively systematic research on the role of the state in the process of institutional change of agriculture, but his research focus was on the game of decision making among the state, collective managerial personnel and peasants in the institutional change of Chinese rural areas, (Zhou Qiren, 1995). On the foundation of studies by previous researchers, this article employed the analytical method of State Theory by North to analyze reasons for adjustment by the state to agricultural land system after the founding of PRC and study the role of the state in institutional change of agricultural land.

\section{Review on developmental progress of agricultural system after the founding of PRC}

In the process of three times' institutional changes of rural land after the founding of PRC, formulation of peasants' land property right had different models and levels of agricultural development also exhibited significant differences. The National Land Meeting held in 1947 established the private ownership of land of "land to the tiller", which motivated enthusiasm of farmers' production and improved highly efficiency of agriculture. In 1952, the nation began to carry out the strategy of heavy industrialization. At each stage of 
agricultural collectivization, agricultural production also exhibited different development levels. From 1952 to 1958, since peasant households still possessed element access right, crop decision rights, stock appreciation right and earning right, agricultural products increased in successive years. From 1959 to 1962, because stimulation to farmers was greatly reduced as a result of bad weather for three consecutive years, policy slippage, bad management of cooperative society and invalidation of management and supervision, and the freedom right of farmers to withdraw from the cooperative society was deprived of, the protocol forcibly implemented in a peasant household had no means to be maintained, which further weakened stimulation to production of farmers. As a consequence, production severely slid within the three consecutive years, (Justin Lin, 2008). However, during the adjustment period of the three years from 1963 to 1965, accounting unit in rural areas was changed from people's commune to production team, which, to a great extent, strengthened supervision among different members, intensified self constraint of members and enhanced enthusiasm of farmers in production. During this period, the average annual growth rate of agriculture was $11.5 \%$, whereas the average annual growth rate of agriculture from 1966 to 1978 was only 2.29\%, (Justin Lin, 2008).

The process of agricultural performance changes during the three times' agricultural institutional changes once again proved the important role of institution in economic development. Just as Schurz pointed out, "Obviously, specific systems are indeed important, and they are frequently changed. And as a matter of fact, they are changing, and people are attempting to make social choice to different institutional changes in order to improve economic efficiency and social welfare" (quoted from Justin Lin). Then, we can find out such an issue from the evolvement of Chinese agricultural land institution, that is, why sometimes the nation could not carry out spontaneous systems, but sometimes volunteered to carry out some systems. What's more, as for the same system, such as family contract responsibility system, why it was sometimes prohibited to be carried out, but was sometimes acknowledged for its legal status?

Although the legal status of family contract responsibility system in Chinese rural areas was not established until 1980 by the Central Government, its development had gone through four stages, (Yoram Barzel, 1997). The first stage is the advanced agricultural producers cooperative in 50s in the Twentieth Century. "Peasants discovered that, only when reward of laborers was measured by means of considering the final output of agricultural crops, could labor paid by laborers be correctly evaluated. Then, the following appeared: 'contract production quotas to individual households', 'contract production quotas to groups' and 'work contracted to households"'. The second stage is during autumn of 1956, when rural areas in such many provinces as Anhui, Sichuan and Jiangsu, etc, carried out "contract production quotas to individual households", or expanded their private plots. The third stage was from 1961 to 1962 when inadequacy of stimulation of collectivization activities, invalidation of supervision and inappropriate management were brought to complete disclosure under the influence of natural disasters. Living of peasants was extremely harsh, and their subsistence was encountered with serious threat, under which circumstance the third "contract production quotas to individual households" which originated from Anhui Province was widely carried out in many areas. This activity aroused high attention from the Central Government, and was finally called to failure by the Central Government transferring the production accounting unit from People's Commune to Production Team, which was a setback of collectivization policy. The final stage was in 1978 when "contract production quotas to individual households" arose again in Anhui and Sichuan, etc, which received its legal status finally by being acknowledged by the nation. The following part of this article is going to make an analysis in Chinese agricultural land change by employing the State Theory by North and come to corresponding conclusions.

\section{Overview of the State Theory by North}

"Existence of the nation is indispensable to its economic growth, but sometimes it is believed to be the root cause of economic recession", (North, 1992). Therefore, the role of the nation has to be involved in research on the course of economic development. A state has the following characteristics: a state is an organization with comparative advantages in implementation of violence. At the same time, due to the exclusiveness of property right, the state with comparative advantage in implementation of violence is in a position of stimulating and forcibly bringing property right into effect. That is, the state may have and has the ability to make use of violence to realize its control over resources, (Justin Lin). "In any society, the highest authority is manipulated by one politician who, more or less, is not affected by preference and pressure of the citizens. Thus, one relatively satisfactory analytical way is to regard the decision making of the state as a process which is finished through behavior of the politician," (North, 1992). "Similar to any individual with bounded rationality, the governor is also concerned about his own subsistence, authority, right, health and historical status, etc," (North, 1992). "Anything the governor intends to do, in his eyes, is a matter which is enough to maximize his own utility." A view of North's analysis in the state, it can be found that, he believed the functions which constituted the 
maximization of utility of a governor included security of governing, maximization of rent and maximization of revenue, etc. According to different roles of a state in economic growth, the behaviors of the state can be analyzed from the following two theories, namely, Pillage Theory and Contract Theory.

According to the Pillage Theory, a state is an agency of a group or a class, and its function is to squeeze income of other voters on behalf of interests of that group or class. A state may draw up a set of property right structures to maximize annual income of the group holding power. This theory focuses on how those people manipulating the nation squeeze land tax of the voters. According to the Contract Theory, a state carries out a system and reduces transaction costs to provide irritative ownership structure (that is, a group of property rights which enable personal returns rate of innovation and human capital investment to approach to social returns rate), (North, 1992). for effective resource allocation, that is, property rights with effective rate in the hope of maximizing the total output and social welfare and making the nation obtain maximized tax revenue, (North, 1992). "Contract Theory assumes that potential of violence is equally distributed, whereas Pillage Theory assumes unequal distribution." Either maximization of land rent or maximization of tax revenue is favorable to increase utility of a governor, but the premise of the two is to guarantee security of the governor. Therefore, only when security of governing is guaranteed, can the state exercise protection to property right of land rent maximization. And only if rent and income is not reduced, can the governor put into effect the effective property right structure to diminish transaction cost so as to increase tax revenue. On the contrary, if the property right with efficiency may reduce rent income of the governor or threaten security of governing, then the governor would still maintain the original inefficient property right. In other words, only property right with efficiency which can enhance or at least do not diminish security of governing or rent income of the governor can be supported by the nation and thus be put into effect.

\section{Analysis in the role of the nation in the process of agricultural land institution in China}

According to the State Theory by North, there are the following reasons why the nation implements property rights with inefficiency: inconformity of utility of the agency with that of the governor, comparison between profits to define a property right and expenditure, restraint of competition, and the fact that expenses caused by implementation of property rights with efficiency might reduce rent income, etc. This section of the article is going to make an analysis in background and causes in implementation of different agricultural land policies by the nation by reference to the process of institutional change of Chinese agricultural land.

\subsection{Property right policy implemented due to restraint of competition}

A governor always has a competitor who might come from the competitive nation or might become another governor of the nation and who make threats to the security of governing by the governor. Security of governing by the governor originates from support of his voters. As for voters, their support to the governor depends on comparison between support profit and support cost. Under the circumstance with unchanged support cost, the more profits of support to the governor, the more support from the voters. Out of consideration of the security of governing, the governor would tend to make some arrangement about property rights in the hope of increasing support profits of the voters, regardless of whether the arrangement would be favorable for boosting economic development. That is to say, arrangement of property right made the governor is restricted by restraint of competition.

The most typical property right policy implemented by the state to realize security of governing was the private ownership of land from 1947 to 1952. In 1947, Chinese Communist Party held a National Land Meeting in Xibaipo and established the private land ownership system of "land to the tiller". With help of the national political power, farmers acquired land, which, to a great extent, mobilized farmers' enthusiasm in production and increased their income, and which, naturally, strengthened recognition and support by the government, their enthusiasm in joining in the army running high. Out of consideration for security of obtaining the governing position, the governor adopted the policy of private ownership of land in order to gain more support revolutions by the public, which objectively formed effective property rights. This system reduced greatly relevant transaction costs (such as, compared with other agricultural land systems, private ownership of land might reduce expenses of supervision or expenses of collaboration) and promoted improvement of agricultural efficiency. In 1952, the total agricultural output and grain output respectively increased by $48.5 \%$ and $42.8 \%$ compared with that in 1949, (Justin Lin, 2008).

Another case in Chinese agricultural history to carry out the property right policy as a result of restraint of competition was the policy adjustment from 1962 to 1965. During that period, there was the background of the three years' natural disaster from 1959 to 1962 , and the "serious famine (that is, a part of rural population had lower grain ration than what was needed for subsistence, and approximately 30 million population died from the 
famine) had already spread, so economic crisis escalated into the political crisis of challenging authority of decision makers and the legality of the government", (Justin Lin). At that time, the nation cancelled temporarily the right of distribution of People's Commune, and changed the original accounting unit into the Production Team. After the crisis, the nation again recovered the original collectivization policy for implementation of heavy industrialization strategy.

The two property right policies implemented to guarantee security of governing in the process of Chinese agricultural land evolvement coordinated the security target of governors and the target of revenue maximization and were adjustment with Pareto improvement significance.

\subsection{Restraint to comparison between profits and expenses to define property rights}

Activities of defining property rights by a governor to realize maximization of rent were affected by profits and costs to define property rights. When expense (marginal cost) for defining some resource was huger than profit (marginal cost) of defining the resource, it meant that maximization of utility was not fulfilled. That is to say, the governor would not define property rights of this part of resource which would then be brought into sphere of public and become public resource. On the contrary, when profit of defining some resource was huger than expense for defining the resource, the governor would define property rights of the resource. Collectivization meant that a state had conducted economic activities to define collective economic resources, and expense for defining these resources could be measured by expenditures of the national finance and financial departments to support agricultural development, expenditures to maintain operation of collective economic system and investment output of corresponding ideology, whereas profits of defining resources included agricultural land tax, support of agriculture to industry and political support of peasants. It was indicated by Zhou Qiren's study, during the two historical periods of the third and fourth contract production quotas to individual households, gaps between expenses and profits of collectivization system were the two climaxes during the thirty years from 1952 to 1982 . This proved that net cost incidence brought about by collectivization was too heavy and had exceeded external profits to implement this system, which not only affected rent income, but more important, the economic crisis caused by collective economy threatened power of decision makers and led to political crisis which challenged legality of the government. That is to say, "as a result of the wrong economic policy for long, abuse of the national authority by leaders and the crisis of succession of the highest power, the absolute authority of the state to the society was largely weakened", (Justin Lin). Under such a circumstance, the state again made corresponding policy adjustment. For instance, the third activity of contract production quotas to individual households transferred the distribution unit into the production team, and the fourth activity of contract production quotas to individual households broke through the institutional framework of collective economy, which ultimately established the family contract responsibility and thoroughly changed original resource allocation forms.

\subsection{Property right with inefficiency caused by inconformity between utility function of the agency and that of the governor}

Sometimes, even if existing property right could fulfill both the target of maximization of rent and the target of maximization of tax, it could not realize economic growth since the utility function of the agency of the governor was not totally identical with that of the governor. Moreover, in most cases, a property right was not able to guarantee fulfillment of two targets at the same time. The spatial characteristics of agricultural production and the organic characteristics of production subjects determined that agricultural output was subject to attempt of agricultural producers to a great extent. However, the distribution mechanism in collective system was not favorable to stimulate enthusiasm of producers, and at this time, effective supervision mechanism became the necessary condition for members of collective economy to make enough efforts. As a matter of fact, the actual superintendents in rural collective economic activities in China were all first-class cadres in villages who had not entered the formal administrative rank sequence of the nation. Therefore, they were not stimulated for promotion in terms of administrative ranks. Simultaneously, the distribution system of collective economy had no means to give them any surplus of products, which indicated that, the stimulation mechanism in collective economy was not enough to stimulate enthusiasm of the superintendents. That is to say, utility of agencies was not in conformity with that of the governor. Thus, as a result of inefficient supervision mechanism, and moreover as a consequence of inconformity between utility function of agencies and that of the governor, collective economy once again fell into a condition with low efficiency.

\subsection{Property right with inefficiency implemented in order to guarantee rent income}

After the founding of PRC, the strategy of heavy industrialization of the nation in 1952 was induced to be established owing to such factors as the status quo of the agricultural nation, successful experience of Russia in 
heavy industry and political isolation and economic blockade after the beginning of the Korean War. In order to fulfill this target, limited funds at home had to be employed into the field of heavy industry and a series of agricultural institutional reforms were conducted to manpower and land in agriculture with the agricultural system of collectivization as the center, including mandatory plans, planned purchase and marketing by the state, prohibition to long-distance transport of goods for sale and restraint to free trade, which were aimed at guaranteeing implementation of the national strategy and realize maximization of rent. Although the collective economic system in Chinese rural areas was helpful for implementation of the heavy industrialization strategy, collective economy should pay for extra expenses of operation of the collective economic system compared with the private ownership of land during the previous period. That is to say, this system increased transaction cost of economic activities and reduced economic performance, so implementation of this system did not have any significance of Pareto improvement.

\section{Conclusions}

Similar to characteristics embodied in the institutional evolvement in the history of human beings, Chinese agricultural land system was also finished under push of the national power. System of equal distribution of agricultural land resources among peasant households (the private land ownership system and family contract responsibility system) was identical with the starting point of the Contract Theory, that is, to assume resources were distributed equally among the citizens. The system of centralized allocation of agricultural land resources (collectivization economic system) was identical with the starting point of Pillage Theory, that is, to assume resources were unequally distributed among the citizens. Of course, the essence of both was distribution of resources by the governor to realize maximization of utility. In this process, effective property right structures would be formed, such as family contract responsibility system, characterized by reducing transaction cost and stimulating enthusiasm in production.

\section{References}

Chen, Xiwen, Zhao, Yang \& Luo, Dan. (2008). 30 Years of Reform in Chinese Rural Areas: Retrospect and Prospect. People's Publishing House, December.

Douglass C. North. (1992). Structure and change in economic history. The Commercial Press.

Justin Lin. (2008). Institution, Technology and Agricultural Development in China. Gezhi Publishing House, Shanghai Joint Publishing Co., Ltd \& Shanghai People's Publishing House, April.

Justin Lin. Economics Theory about Institutional Changes --- Induced Change \& Mandatory Change.

Yoram Barzel. (1997). Economic Analysis of Property Rights, translated by Fei, Fangyu \& Duan, Yicai. Shanghai Joint Publishing Co., Ltd \& Shanghai People's Publishing House, June.

Zhou, Qiren. (1995). Reform in Chinese Rural Areas: Changes of Relationship between the State and Property in Land. Hongkong: Chinese Social Sciences Quarterly, No. 6. 